\title{
Integrating Data from Discrete Return Airborne LiDAR and Optical Sensors to Enhance the Accuracy of Forest Description: A Review
}

\author{
Cong $\mathrm{Xu}^{1} \cdot$ Justin $^{\text {Morgenroth }}{ }^{1} \cdot$ Bruce Manley $^{1}$
}

Published online: 12 July 2015

(C) Springer International Publishing AG 2015

\begin{abstract}
Good forest management requires comprehensive and reliable inventory data spanning large areas. Forest management has increasingly relied on remote sensing, specifically light detection and ranging (LiDAR). However, due to the high costs associated with data collection and processing, wall-to-wall LiDAR data is rarely obtained for forests. In contrast, multispectral imagery from optical sensors often covers large extents but they fail to capture detail below the forest canopy and do not directly measure structural attributes. To take advantage of the complementary benefits of different sensors, active LiDAR and passive optical sensors have been combined and applied to problem-solving in a forestry context for over a decade. A review of the literature shows that fusion of different sensors has resulted in superior performance relative to individual sensors for classifying and delineating forest areas (up to $20 \%$ accuracy improvement), identifying species (up to $21 \%$ accuracy improvement), and estimating forest volume and biomass (up to $55 \%$ accuracy improvement). In contrast, sensor fusion achieved only minor improvements for tree or forest height estimation (1-7\% accuracy improvement); this is likely because LiDAR alone is already so effective. This review was unable to draw conclusions on the performance of sensor fusion for forest age and productivity assessment due to the limited number of studies. The lack of
\end{abstract}

This article is part of the Topical Collection on Remote Sensing

Cong Xu

cong.xu@pg.canterbury.ac.nz

Justin Morgenroth

justin.morgenroth@canterbury.ac.nz

Bruce Manley

bruce.manley@canterbury.ac.nz

1 School of Forestry, University of Canterbury, Private Bag 4800, Christchurch, New Zealand results in these areas presents an opportunity for future research. The literature clearly demonstrates the utility of integrating LiDAR and optical data for many aspects of forest description. Perhaps the greatest challenge moving forward will be to operationalise the research such that forestry companies and governments can take advantage of the benefits of data fusion.

Keywords Forest description - Forest mensuration - Aerial laser scanning $\cdot$ Optical sensor $\cdot$ Remote sensing $\cdot$ Sensor fusion

\section{Introduction}

Forests provide timber and non-timber products, habitats for a diverse range of flora and fauna, as well as social benefits such as shelter, food and employment. Managing forests to optimise one or more of these benefits is challenging as they are dynamic and undergo continual change from both natural and human-induced afforestation and deforestation [1]. Effective forest management requires comprehensive forest data for a range of temporal and spatial scales. However, obtaining full descriptive data from ground-based approaches is often unfeasible [2]. Remote sensing, including aerial photography, satellite imagery, and light detection and ranging (LiDAR), has increasingly been used as a means of cost-effectively capturing forest data $[2,3]$.

Aerial photography is the most widely used remote-sensing technique in forest management [4]. Image characteristics such as shape, pattern and texture are used to delineate forest stand boundaries [5], estimate tree height and crown diameter [6] and identify species [7]. Kovats [8] demonstrated that tree height can be measured using high-resolution stereoscopic aerial photos with photogrammetric techniques to measure 
the lengths of shadows projected onto the ground. Likewise, Dandois and Ellis [9] accurately measured tree height on aerial photos using a computer vision technique. However, these techniques have not been applied operationally as they are dependent on a number of factors including presence of open flat ground and specified sun elevation and angle. Furthermore, subjective interpretation often results in inconsistent degrees of precision and accuracy [10].

Apart from aerial photography, research has increasingly employed satellite imagery in forest assessment. Satellite multi- and hyperspectral sensors capture the electromagnetic radiation emitted by the sun and reflected by the earth's surface [11]. Spectral and contextual attributes derived from satellite sensors can be modelled against empirically derived biophysical features of the forest, such as stand basal area, height and crown closure [12,13], stand density [14], leaf area index (LAI) [15-17] and forest volume and biomass [18-20]. Development of textural analysis such as the grey-level cooccurrence matrix (GLCM) has also allowed the use of additional information from optical sensors to assess forest stand variables such as height, basal area and stand density [21]. Recently, high-resolution satellite imagery (sub-metre) has been used to measure forest structural variables at a finer scale, which makes possible automated detection of individual trees via crown delineation, and modelling individual tree crown size, height, diameter, volume, age class and species composition [3, 21-23].

Advantages of optical sensors include large coverage of forest area, easy access and low cost [24.•]; consequently, data from optical sensors are useful for large-scale forest assessment and monitoring [25]. The key limitation of passive optical sensors is that they cannot capture detail below the forest canopy and hence cannot directly measure vegetation structure [26].

LiDAR, an active sensor, has been increasingly used in forest assessment. LiDAR directly measures canopy height, which is a commonly used attribute to describe forest structure [27]. Allometric relationships between tree height and diameter at breast height $(\mathrm{DBH})$ have been derived for various tree species [28-30], and these two variables are commonly used to derive volume [31]. LiDAR-measured heights, together with other LiDAR-derived metrics (e.g. penetration metrics), are important for modelling other structural attributes, such as canopy cover [32], stem density [33], basal area [34], biomass $[35,36]$, volume [37] and LAI [38].

LiDAR is demonstrably superior to passive optical sensors for assessing forest structural variables, especially canopy height $[39,40]$. Discrete return airborne LiDAR systems now collect stand-level and regional wall-to-wall forest structure attributes (tree height, stand volume and basal area) in the national inventory programmes of Finland, Norway and Sweden $[36,41]$. Despite these examples, the high cost of LiDAR acquisition and lack of processing expertise generally preclude wall-to-wall LiDAR surveys for operational use [4, 42].

In order to overcome the limitations of individual sensors and optimise the advantages of different types of sensors, discrete return LiDAR and optical sensors have been integrated to provide more comprehensive and accurate characterisation of forest structure and dynamics [27]. The intention is to keep the acquisition cost low [43] while using the relationship between LiDAR and optical data to better describe a larger extent of the forest resource [44]. Combined use of optical images and LiDAR in forestry utilises both the spectral information in optical imagery and the 3-D information in LiDAR. Therefore, when combining LiDAR and optical spectral sensors, additional information from both sensors is integrated and more accurate results are expected.

Since optical sensors and discrete return LiDAR have been extensively studied and applied in forestry, a number of reviews on their individual use have been conducted $[2,3$, $45-48,49 \bullet \cdot, 50,51]$. However, no comprehensive review of the fusion of discrete return LiDAR with optical sensors has been conducted despite more than a decade having passed since the first integrated study of discrete return LiDAR and Landsat ETM $+[24 \cdot \bullet]$. We address this gap in the literature by reviewing research into the combined use of discrete return LiDAR and optical sensors across a broad range of applications in forestry, specifically with respect to forest delineation and classification, and estimating forest age, species and forest structural variables. This review is limited to sensor fusion studies where multi-sensors are used simultaneously to assess forest attributes.

\section{Fusion of LiDAR and Optical Sensors}

\section{Forest Delineation and Classification}

Forest classification and forest boundary delineation are important in both natural and planted forest management in assessing forest types and areas, as understanding forest area and location is fundamental for a broad field of applications and users [52]. Aerial photography is most commonly used to determine forest area through manual interpretation. However, forest stand delineation based on manual interpretation of aerial photos can be highly subjective and time-consuming. Forest cover type classification can be achieved by automated image classification by assigning forest cover types and estimating forest variables based on the spectral, textural and auxiliary information in the image. This produces a more objective delineation and reduces time and associated costs [53].

LiDAR data adds a new source of information for forest classification and delineation through direct estimation of forest canopy size and height. Incorporating LiDAR into optical sensor mapping utilises both spectral and structural 
information to achieve a more accurate forest classification. Nordkvist et al. [54] integrated low-density discrete return airborne LiDAR-derived height metrics with SPOT 5 HRG spectral information for vegetation classification in Sweden and achieved $16.1 \%$ improvement in classification accuracy compared to using SPOT only. The study also compared maximum likelihood and object-based decision tree classification approaches and found the best accuracy was achieved by decision tree classification. Sasaki et al. [55•] achieved a minor improvement in overall land cover classification accuracy $(95$ to $97.5 \%$ ) by an object-based classification approach integrating inputs from high-resolution spectral images captured by digital camera with LiDAR-derived metrics including height, ratio, pulse and intensity parameters. Additionally, Bork and $\mathrm{Su}$ [56] used a maximum likelihood approach to classify eight vegetation classes. Using only airborne LiDAR inputs achieved lower accuracy than using only a digital multispectral image; however, the fusion of LiDAR and multispectral imagery increased classification accuracy by $15-20 \%$. A more recent study explored the benefits of incorporating a digital elevation model (DEM) and digital surface model (DSM) derived from LiDAR into tropical forest mapping using SPOT 5 HRG imagery. This approach enhanced image segmentation and successfully differentiated six vegetation classes, producing an overall forest classification accuracy of $91 \%[57 \cdot]$.

The combination of aerial photography and LiDAR has also commonly been used for forest delineation. Wang et al. [58] developed an approach to automatically delineate forest boundaries using both aerial photography and a LiDARderived canopy height model (CHM) for the National Forest Inventory of Switzerland. The approach involved two processes: (1) detecting forests using a moving window over the CHM and delineating forest boundaries by analysing the CHM-derived curvature value, vegetation index and (2) using textural values of segmented image objects. Although there are no statistical improvements calculated, the visual results relative to manual digitisation looked very promising. Haywood and Stone [59] developed an automated approach that transforms aerial photos and LiDAR CHM into vectorised forest stand boundaries ( $65 \%$ overall accuracy). The study did not explicitly show an improvement using sensor fusion, but it demonstrated the possibility of operationalising the fusion of optical sensor and LiDAR in natural forests stand delineation.

A summary of recent studies using integrated LiDAR and optical sensors is shown in Table 1. All of these studies have either shown an improvement (up to $20 \%$ ) in forest classification results compared to using a single sensor or made it possible to discriminate further forest classes that otherwise could not be identified by single sensors. All studies reviewed in this section used discrete return LiDAR and other optical sensors. LiDAR data has been acquired at point densities ranging from 0.54 to 11.3 points $/ \mathrm{m}^{2}$, with all but one study reporting point density lower than 2 points $/ \mathrm{m}^{2}$. It appears that low-density LiDAR is sufficient to classify forest types and delineate forest boundaries when integrated with optical sensors, as only the interpolated LiDAR surfaces are used as inputs.

When a fusion approach is used, the common approach to classify forest types and delineate forest boundaries is image classification based on inputs derived from both LiDAR and optical sensors. Machala and Zejdova [60] listed 26 customised arithmetic features derived from discrete return LiDAR and multispectral sensor data that are useful inputs for classifying forest covers. The inputs are commonly rasterised and applied with automated image classification analysis. There is a clear trend towards the use of objectbased image analysis (OBIA) rather than pixel-based classification like the maximum likelihood approach. Pixel-based image classification that ignores spatial association among pixels, tends to be sensitive to spectral variations; hence, it is likely to result in a relatively high level of misclassification [61]. OBIA overcomes the issues by carrying out classification on segmented objects that are similar to real land cover features in size and shape [62]. The approach allows consideration of multiple image elements and scales such as texture, shape and context, as opposed to pixel-based classification that solely relies on the pixel values. Overall, OBIA has been proven to produce more accurate classification results compared to a pixel-based approach with single sensor analysis [63]. This may explain why OBIA is favoured in forest classification and delineation with integrated sensors. The statistics to evaluate the performance of forest type classification include classification accuracy matrices or confusion matrices, which compare the classified classes against reference classification and generate a series of statistics such as overall classification accuracy, producer's and user's accuracy and kappa coefficient [64].

\section{Forest Species}

Accurate characterisation of species is important in forest management, resource planning and monitoring. Remote sensing technologies have been widely used for forest species classification $[22,65]$. The recent development of laser scanning also offers the possibility of automatically identifying individual trees and obtaining height and canopy measurements from them [66-68], hence providing the possibility of classifying individual tree species [69].

More accurate species classification is expected from the fusion of LiDAR and other sensors due to the synergy of both structural and spectral data. Holmgren et al. [69] used airborne LiDAR-derived height, canopy and intensity parameters to delineate individual tree crowns and calculate tree crown heights and areas then identified tree species for delineated tree crowns using a maximum likelihood approach by 
Table 1 Recent studies of forest classification and delineation using integrated LiDAR and optical sensors

\begin{tabular}{|c|c|c|c|c|c|c|}
\hline $\begin{array}{l}\text { Forest species/ } \\
\text { type }\end{array}$ & $\begin{array}{l}\text { Remote-sensing data } \\
\text { used }\end{array}$ & Metrics derived & $\begin{array}{l}\text { Estimated } \\
\text { parameters }\end{array}$ & Approach & Accuracy/error & Reference \\
\hline $\begin{array}{l}\text { Mixed tropical } \\
\text { forest reserves }\end{array}$ & $\begin{array}{l}\text { Discrete return airborne } \\
\text { LiDAR }\left(2 \text { points } / \mathrm{m}^{2}\right), \\
\text { aerial photo (AP) and } \\
\text { SPOT5 HRG }\end{array}$ & $\begin{array}{l}\text { LiDAR-derived } \\
\text { DEM and DSM, } \\
\text { spectral bands } \\
\text { from AP and SPOT }\end{array}$ & $\begin{array}{l}\text { Forest type } \\
\text { classification }\end{array}$ & $\begin{array}{l}\text { Image segmentation } \\
\text { and multi-level } \\
\text { decision-tree } \\
\text { classification }\end{array}$ & $\begin{array}{l}\text { Overall classification } \\
\text { accuracy, } 91 \%\end{array}$ & {$[57 \bullet]$} \\
\hline $\begin{array}{l}\text { Wetland forests } \\
\text { including } \\
\text { pine, } \\
\text { spruce and } \\
\text { birch }\end{array}$ & $\begin{array}{l}\text { Discrete return airborne } \\
\text { LiDAR }(1.6 \\
\left.\text { points } / \mathrm{m}^{2}\right) \text { and } \\
\text { SPOT5 } \mathrm{HRG}\end{array}$ & $\begin{array}{l}\text { SPOT spectral bands, } \\
\text { LiDAR-derived } \\
\text { height, canopy returns }\end{array}$ & $\begin{array}{l}\text { Vegetation } \\
\text { classification }\end{array}$ & $\begin{array}{l}\text { Supervised maximum } \\
\text { likelihood and } \\
\text { decision tree } \\
\text { classification }\end{array}$ & $\begin{array}{l}\text { Overall accuracy } \\
\text { SPOT only, } \\
55.8 \% \text {; combined } \\
\text { SPOT and LiDAR, } \\
71.9 \%\end{array}$ & {$[54]$} \\
\hline $\begin{array}{l}\text { Mixed forest } \\
\text { dominated } \\
\text { by oak }\end{array}$ & $\begin{array}{l}\text { Discrete return small- } \\
\text { footprint airborne } \\
\text { LiDAR } \\
\left(11.3 \text { points } / \mathrm{m}^{2}\right) \text { and } \\
\text { simultaneously } \\
\text { collected NIR digital } \\
\text { image }(0.18 \mathrm{~m})\end{array}$ & $\begin{array}{l}\text { Spectral bands and } \\
\text { NDVI from digital } \\
\text { image; LiDAR- } \\
\text { derived DEM, } \\
\text { CHM and intensity }\end{array}$ & $\begin{array}{l}\text { Land cover } \\
\text { classification } \\
\text { and species } \\
\text { classification }\end{array}$ & $\begin{array}{l}\text { Image segmentation } \\
\text { and object-based } \\
\text { decision tree } \\
\text { classification }\end{array}$ & $\begin{array}{l}\text { Overall accuracy } \\
\quad \text { digital image only, } \\
95 \% \text {; combined } \\
\text { with LiDAR, } \\
97.5 \%\end{array}$ & {$[55 \bullet]$} \\
\hline $\begin{array}{l}\text { Natural } \\
\text { eucalyptus } \\
\text { forest }\end{array}$ & $\begin{array}{l}\mathrm{AP} \text { and discrete return } \\
\text { airborne LiDAR } \\
\left(0.96 \text { points } / \mathrm{m}^{2}\right)\end{array}$ & $\begin{array}{l}\text { Textural and spectral } \\
\text { information from } \\
\text { aerial photo, } \\
\text { LiDAR-derived CHM }\end{array}$ & $\begin{array}{l}\text { Forest stand } \\
\text { delineation }\end{array}$ & $\begin{array}{l}\text { Automated imagery } \\
\text { segmentation }\end{array}$ & $\begin{array}{l}\text { Overall accuracy } \\
\text { of } 65 \%\end{array}$ & [59] \\
\hline $\begin{array}{l}\text { All forests in } \\
\text { Switzerland } \\
\text { (National } \\
\text { Forest } \\
\text { Inventory) }\end{array}$ & $\begin{array}{l}\text { AP and discrete return } \\
\text { small-footprint } \\
\text { airborne LiDAR }\end{array}$ & $\begin{array}{l}\text { AP-derived vegetation } \\
\text { indices (VI), } \\
\text { textural information } \\
\text { and LiDAR-derived } \\
\text { CHM }\end{array}$ & $\begin{array}{l}\text { Forest detection } \\
\text { and } \\
\text { delineation }\end{array}$ & $\begin{array}{l}\text { Decision tree using } \\
\text { CHM, curvature } \\
\text { feature and VI }\end{array}$ & Visual results only & {$[58]$} \\
\hline $\begin{array}{l}\text { Mixed } \\
\text { vegetation } \\
\text { in rangeland } \\
\text { including } \\
\text { aspen forest }\end{array}$ & $\begin{array}{l}\text { Discrete return airborne } \\
\text { LiDAR }(0.54 \\
\left.\text { points } / \mathrm{m}^{2}\right) \text { and } \\
\text { simultaneously } \\
\text { collected digital } \\
\text { image }(0.5 \mathrm{~m})\end{array}$ & $\begin{array}{l}\text { LiDAR height and DEM, } \\
\text { RGB, digital image } \\
\text { intensity and hue }\end{array}$ & $\begin{array}{l}\text { Vegetation type } \\
\text { classified }\end{array}$ & $\begin{array}{l}\text { Supervised maximum } \\
\text { likelihood } \\
\text { classification } \\
\text { and decision tree }\end{array}$ & $\begin{array}{l}\text { Overall classification } \\
\text { accuracy for } \\
\text { LiDAR and image } \\
\text { only is } 64.8 \text { and } \\
74.6 \% \text {, } \\
\text { respectively; } \\
\text { integrated } \\
\text { approach, } 91 \%\end{array}$ & {$[56]$} \\
\hline
\end{tabular}

integrating LiDAR data with features from high-resolution digital mapping camera (DMC) digital images. The overall species classification accuracy was $96 \%$, which was an improvement from using LiDAR (91\%) and digital imagery (88\%) individually. Ke et al. [70] evaluated the combined spectral and textural layers from QuickBird imagery and topography, canopy height and intensity from low-density LiDAR ( 0.16 points $\left./ \mathrm{m}^{2}\right)$ for forest species classification, using object-based segmentation and machine-learning decision trees. The highest classification accuracy (kappa $=91.6 \%$ ) was achieved using both spectral and LiDAR-derived metrics with accuracies that were $20 \%$ greater than those that used individual sensors. Sasaki et al. [55 ${ }^{\circ}$ ] classified 16 tree species with high density $\left(11.3\right.$ points $\left./ \mathrm{m}^{2}\right)$ airborne discrete return LiDAR and multispectral imagery. Although the objectbased decision tree classification produced low overall accuracy $(31.5 \%)$, a $17 \%$ improvement was made with inputs from both sensors. Some species such as pine and poplar gained significant improvement (32 and $56 \%$, respectively) with sensor fusion compared with using digital images only. A more recent study used very high-resolution WorldView-2 images and discrete return airborne LiDAR for object-based species classification in a temperate rainforest in Australia. It utilised the spectral features and GLCM textures from the images and a LiDAR-derived CHM and associated statistics to conduct an object-based decision tree classification on a mixture of natural and plantation forest species. The accuracy for LiDAR-only and image-only species classification was 61 and $70 \%$, respectively, whereas combined sensors improved species classification to $82 \%$ [71•].

Hyperspectral sensors have also been integrated with LiDAR in forest species classification. Several studies have indicated fusion between hyperspectral and LiDAR data enhances forest species differentiation. Dalponte et al. [72] tested leave-one-out covariance (LOOC), support vector machines (SVM) and k-nearest neighbour (k-NN) classifiers for forest species classification using hyperspectral bands and a LiDAR-derived CHM. The best classification accuracy was found using SVM. In total, 23 tree species classes were successfully identified with the technique, with some classes over 
$90 \%$ accurate. The overall kappa accuracy using combined sensors was $89.2 \%$, which was slightly higher than using individual sensors (hyperspectral only: $87.9 \%$, LiDAR only: $89 \%$ ). Jones et al. [73] applied similar datasets and techniques to classify more than ten forest species classes. They found most species classes gained accuracy improvement with fusion of hyperspectral and LiDAR inputs (ranging from 0.3 to $19 \%$ ) although the overall accuracy improvement was only minor $(1.2 \%)$.

The way that sensor fusion has been performed is that highresolution optical imagery defines forest stand boundaries and provides spectral separation between different forest species. The addition of LiDAR-derived topographic and height and intensity information further reduces within-class spectral variations caused by topography and enhances variations between species classes as different tree species tend to have different heights [70]. Recent studies integrating LiDAR with other sensors to estimate forest species are shown in Table 2. These studies show that sensor fusion has improved the accuracy of species identification and classification by up to $21 \%$. It is worth noting that species classification from sensor fusion approaches has yielded high variation in accuracies, ranging from 48.4 to $96 \%$ as a result of large variations in species composition in these studies. Discrete return airborne LiDAR was the most common sensor type and the range of point densities was large, spanning $0.16-50$ points $/ \mathrm{m}^{2}$. The point density of LiDAR acquisitions for species classification was generally higher than for forest area delineation. As with forest area classification, object-based decision tree classification is predominantly used in species classification with LiDAR and multispectral sensors.

Hyperspectral sensors capture finer details in the spectral signature (i.e. narrower spectral bands) than multispectral sensors, which allow more detailed differentiation between similar forest types [72]. Generally, hyperspectral sensors alone have shown promising capability in species classification probably due to high spectral resolution. This explains why only minor improvements in species classification accuracy were observed when LiDAR was added (Table 2). Despite high species classification accuracy using only hyperspectral imagery (relative to multispectral imagery), there is no evidence to suggest that fusion of LiDAR and hyperspectral

Table 2 Recent studies of forest species identification using integrated LiDAR and optical sensors

\begin{tabular}{|c|c|c|c|c|c|c|}
\hline $\begin{array}{l}\text { Forest species/ } \\
\text { type }\end{array}$ & $\begin{array}{l}\text { Remote sensing data } \\
\text { used }\end{array}$ & Metrics derived & $\begin{array}{l}\text { Estimated } \\
\text { parameters }\end{array}$ & Approach & Accuracy/error & Reference \\
\hline $\begin{array}{l}\text { Cool temperate } \\
\text { rain forest }\end{array}$ & $\begin{array}{l}\text { Discrete return } \\
\text { airborne LiDAR } \\
\text { and WorldView-2 }\end{array}$ & $\begin{array}{l}\text { Spectral and textural } \\
\text { information from } \\
\text { WorldView-2; } \\
\text { LiDAR-derived } \\
\text { CHM and DEM }\end{array}$ & $\begin{array}{l}\text { Forest species } \\
\text { classification }\end{array}$ & $\begin{array}{l}\text { Object-based } \\
\text { classification } \\
\text { using decision trees }\end{array}$ & $\begin{array}{l}\text { Overall accuracy } \\
\text { WorldView-2, } 70.4 \% \text {; } \\
\text { LiDAR, 61.39 \%; } \\
\text { combined sensors, } \\
82.35 \%\end{array}$ & {$[71 \bullet]$} \\
\hline $\begin{array}{l}\text { Mixed forest } \\
\text { dominated } \\
\text { by oak }\end{array}$ & $\begin{array}{l}\text { Discrete return } \\
\text { airborne LiDAR } \\
\left(11.3 \text { points } / \mathrm{m}^{2}\right) \\
\text { and simultaneously } \\
\text { collected digital } \\
\text { image }(0.18 \mathrm{~m})\end{array}$ & $\begin{array}{l}\text { Spectral bands and } \\
\text { NDVI from digital } \\
\text { image; LiDAR- } \\
\text { derived DEM, } \\
\text { CHM and intensity }\end{array}$ & $\begin{array}{l}\text { Land cover } \\
\text { classification } \\
\text { and species } \\
\text { classification }\end{array}$ & $\begin{array}{l}\text { Image segmentation } \\
\text { and object-based } \\
\text { classification } \\
\text { using decision trees }\end{array}$ & $\begin{array}{l}\text { Overall accuracy digital } \\
\text { image only, } 31.5 \% \\
\text { combined sensors, } \\
48.4 \%\end{array}$ & {$[55 \bullet]$} \\
\hline $\begin{array}{l}\text { Mixed deciduous } \\
\text { forest: maple, } \\
\text { beech, pine } \\
\text { and spruce }\end{array}$ & $\begin{array}{l}\text { QuickBird and discrete } \\
\text { return airborne } \\
\text { LiDAR }(0.16 \\
\left.\text { points } / \mathrm{m}^{2}\right)\end{array}$ & $\begin{array}{l}\text { QuickBird spectral } \\
\text { bands; DEM, } \\
\text { terrain layers, } \\
\text { CHM and intensity } \\
\text { from LiDAR }\end{array}$ & $\begin{array}{l}\text { Forest species } \\
\text { classification }\end{array}$ & $\begin{array}{l}\text { Object-based } \\
\text { classification using } \\
\text { machine learning } \\
\text { decision trees }\end{array}$ & $\begin{array}{l}\text { Overall accuracy from } \\
\text { QuickBird only, } \\
63 \% \text {, combined } \\
\text { sensors, } 83 \%\end{array}$ & {$[70]$} \\
\hline $\begin{array}{l}\text { Mixed species } \\
\text { forest } \\
\text { dominated by } \\
\text { Douglas fir }\end{array}$ & $\begin{array}{l}\text { Transect hyperspectral } \\
(2 \mathrm{~m} \text { resolution }) \\
\text { and discrete return } \\
\text { airborne LiDAR } \\
\left(0.4 \text { points } / \mathrm{m}^{2}\right)\end{array}$ & $\begin{array}{l}\text { LiDAR CHM and } \\
\text { canopy volume; } \\
\text { selected } \\
\text { hyperspectral } \\
\text { channels }\end{array}$ & $\begin{array}{l}\text { Forest species } \\
\text { classification }\end{array}$ & $\begin{array}{l}\text { Support vector } \\
\text { machine } \\
\text { classification }\end{array}$ & $\begin{array}{l}\text { Overall accuracy using } \\
\text { only hyperspectral, } \\
72.3 \% \text {; combined } \\
\text { sensors, } 73.5 \%\end{array}$ & [73] \\
\hline $\begin{array}{l}\text { Mixed spruce, } \\
\text { pine } \\
\text { and deciduous } \\
\text { species }\end{array}$ & $\begin{array}{l}\text { Discrete return } \\
\text { airborne LiDAR } \\
\left(50 \text { points } / \mathrm{m}^{2}\right) \\
\text { and DMC }(0.6 \mathrm{~m})\end{array}$ & $\begin{array}{l}\text { Height, canopy, } \\
\text { pulse and intensity } \\
\text { variables from } \\
\text { LiDAR; spectral } \\
\text { bands from DMC }\end{array}$ & $\begin{array}{l}\text { Individual } \\
\text { tree species } \\
\text { identification }\end{array}$ & $\begin{array}{l}\text { Maximum likelihood } \\
\text { classification of } \\
\text { derived individual } \\
\text { tree crown }\end{array}$ & $\begin{array}{l}\text { Overall classification } \\
\text { accuracy for DMC } \\
\text { only, } 88 \% \text {, LiDAR } \\
\text { only, } 91 \% \text {; and } \\
\text { combined sensors, } \\
96 \%\end{array}$ & [69] \\
\hline $\begin{array}{l}\text { Mixed oak } \\
\text { species } \\
(>20 \text { species })\end{array}$ & $\begin{array}{l}\text { Hyperspectral }(1 \mathrm{~m} \\
\text { resolution }) \text { and } \\
\text { discrete return } \\
\text { airborne } \mathrm{LiDAR} \\
\left(5.6 \text { points } / \mathrm{m}^{2}\right)\end{array}$ & $\begin{array}{l}\text { LiDAR DEM and } \\
\text { intensity; selected } \\
\text { hyperspectral } \\
\text { channels }\end{array}$ & $\begin{array}{l}\text { Area of species } \\
\text { composition }\end{array}$ & $\begin{array}{l}\text { SVM, LOOC } \\
\text { and k-NN }\end{array}$ & $\begin{array}{l}\text { Highest kappa accuracy } \\
\text { from hyperspectral } \\
\text { only, } 87.9 \% \text {; LiDAR } \\
\text { only, } 89 \% \text {, combined } \\
\text { sensors, } 89.2 \%\end{array}$ & {$[72]$} \\
\hline
\end{tabular}


sensors classifies species more accurately than fusion of LiDAR and multispectral sensors. The processing of hyperspectral data can add complexity as they contain a vast array of spectral bands, so a feature selection process is required to eliminate any redundant bands [72]. Rather than conventional classification approaches, non-parametric classifiers, especially SVM has been used when classifying hyperspectral data. SVM is a linear binary classifier that assigns a given test sample from one of the possible labels [74]. The application of SVM has improved classification accuracy, analysis time and stability with hyperspectral data [73].

\section{Tree Height}

Canopy height is considered the key attribute for understanding the vertical structure of forests and is a crucial parameter for modelling forest growth. LiDAR is the best remote-sensing method available for tree height measurement [75]. It has been suggested that the use of LiDAR and other sensors can potentially be a substitute for field measured canopy heights [43].

Spectral reflectance in the form of either raw band value or band ratios (e.g. NDVI) is the primary input from satellite imagery when integrated with LiDAR data to estimate height. Combining LiDAR-derived heights with very high-resolution (VHR) imagery and aerial photos provides the means to more accurately segment individual trees hence to estimate forest attributes at the individual tree level [76•]. McCombs et al. [77] combined small-foot print LiDAR and high-resolution digital multispectral imagery captured by Spectral Visions to identify individual stems and estimate plot mean height in two planted pine forests. A focal search function was used to identify the location of individual trees based on LiDAR-derived tree height and NIR reflectance from an image. Tree identification accuracy increased by $7.6 \%$ for high-density plots and $18.8 \%$ for low-density plots using combined sensors. However, no improvement in height was reported using the combined approach. Suárez et al. [78] used high-resolution aerial photography and LiDAR-derived tree canopy model (TCM) to segment individual Sitka spruce trees in order to derive individual tree height. The study found the method successfully estimated individual tree height, especially for larger trees $\left(R^{2}=0.86\right)$. The study only used the combined sensor approach; hence, no comparison with a single sensor was reported. Popescu and Wynne [79] utilised multispectral ATLAS imagery to stratify forest types using maximum likelihood classification, which facilitated the identification of single trees and the estimation of their heights with LiDAR. Single trees were identified using a variable window technique with local maximum focal filtering over both LiDAR and ATLAS features. Minor improvement on height estimation with sensor fusion was observed $\left(R^{2}\right.$ increased by $1 \%$ for pines and up to $3 \%$ for deciduous). A canopy fuel study also observed a minor improvement in canopy height estimation using metrics derived from both LiDAR and DMC imagery compared to LiDAR alone ( $R^{2}$ of 0.957 and 0.935 , respectively). The study also examined the canopy base height which is the lowest green foliage and found a $6 \%$ improvement with the sensor fusion [80].

The fusion of LiDAR and optical sensors has been used in both identifying or delineating individual trees and estimating single tree height. There are a variety of statistical algorithms adopted to predict tree height based on metrics derived from LiDAR and optical sensors. All the height estimation studies we reviewed (Table 3) applied a linear or multiple regression equation solved using ordinary least squares (OLS). Model performances were evaluated by the coefficient of determination $\left(R^{2}\right)$ and root mean square error (RMSE).

Table 3 shows that LiDAR has already proven very accurate in canopy height estimation. Fusion with other optical sensors added little improvement in height estimation accuracy (1-7\%). One study even reported a slight negative influence on height estimation with sensor fusion compared to using LiDAR alone [77]. A benefit of sensor fusion for tree height estimation is that it supports tree delineation, which is difficult to achieve with smallfootprint or lower point density LiDAR alone. All studies in Table 3 acquired low- to medium-density LiDAR, ranging from 1 to 4 points $/ \mathrm{m}^{2}$. The point densities here are lower and have less variation than point densities reported in studies focused on area delineation and species classification. The high $R^{2}$ values are evidence that despite the lower point density, tree and canopy height can be estimated with high accuracy.

\section{Forest Volume and Biomass}

Height and diameter measurements are highly correlated with forest volume and aboveground biomass in deciduous, coniferous and tropical forests [46]. Volume provides an understanding of forest productivity and structure. Forest biomass allows the estimation of the carbon content in forests, which is important for understanding carbon stock changes associated with deforestation, forest degradation and afforestation. Carbon reporting is required to fulfil obligations to international agreements such as the United Nations Framework Convention on Climate Change (UNFCCC) [81]. Additionally, accurate estimation of biomass in forested areas is essential for developing sustainable climate-friendly strategies [82]. Forest volume and biomass can be directly measured in the field through destructive sampling, but usually, they are estimated based on measured variables such as diameter and height. Remote sensing has been widely applied to estimate forest volume and biomass due to extensive coverage and cost efficiency [50].

Fusion of LiDAR and optical sensors has been studied for estimating forest volume and biomass at the individual tree level [83] or plot level [84] and achieves more accurate estimation than single sensors. An early study used smallfootprint airborne LiDAR and multispectral ATLAS imagery 
Table 3 Recent studies of forest height estimation using integrated LiDAR and optical sensors

\begin{tabular}{|c|c|c|c|c|c|c|}
\hline $\begin{array}{l}\text { Forest species/ } \\
\text { type }\end{array}$ & $\begin{array}{l}\text { Remote-sensing data } \\
\text { used }\end{array}$ & Metrics derived & $\begin{array}{l}\text { Estimated } \\
\text { parameters }\end{array}$ & Approach & Results & Reference \\
\hline $\begin{array}{l}\text { Conifer forest } \\
\text { dominated by } \\
\text { ponderosa pine, } \\
\text { Douglas fir, } \\
\text { grand fir and } \\
\text { lodgepole pine }\end{array}$ & $\begin{array}{l}\text { Discrete return } \\
\text { airborne LiDAR } \\
\left(>4 \text { points } / \mathrm{m}^{2}\right) \\
\text { and } \\
\text { simultaneously } \\
\text { collected digital } \\
\text { image }(0.6 \mathrm{~m})\end{array}$ & $\begin{array}{l}\text { LiDAR height } \\
\text { variables and } \\
\text { intensity; } \\
\text { digital } \\
\text { imagery } \\
\text { spectral bands } \\
\text { and NDVI }\end{array}$ & $\begin{array}{l}\text { Canopy fuel } \\
\text { attributes: } \\
\text { canopy } \\
\text { height }(\mathrm{CH}) \text {, } \\
\text { canopy base } \\
\text { height } \\
(\mathrm{CBH})\end{array}$ & $\begin{array}{l}\text { Multiple regression } \\
\text { modelling }\end{array}$ & $\begin{array}{l}\mathrm{CH} R^{2} \text { LiDAR only, } 0.935 ; \\
\text { image only, } 0.415 \text { and } \\
\text { combined sensors, } 0.957 \\
\text { CBH R2 LiDAR only, } 0.783 \text {; } \\
\text { image only, } 0.309 \text { and } \\
\text { combined sensors, } 0.843\end{array}$ & {$[80]$} \\
\hline Sitka spruce forest & $\begin{array}{l}\text { Discrete return } \\
\text { airborne LiDAR } \\
\left(3-4 \text { points } / \mathrm{m}^{2}\right) \\
\text { and aerial photo } \\
(0.25 \mathrm{~m})\end{array}$ & $\begin{array}{l}\text { LiDAR CHM, } \\
\text { aerial photo } \\
\text { bands }\end{array}$ & $\begin{array}{l}\text { Individual tree } \\
\text { height }\end{array}$ & $\begin{array}{l}\text { Segmentation of image } \\
\text { to delineate } \\
\text { individual trees }\end{array}$ & $\begin{array}{l}\text { Combined sensors: } R^{2}=0.69- \\
\quad 0.86\end{array}$ & {$[78]$} \\
\hline $\begin{array}{r}\text { Mixed deciduous } \\
\text { and coniferous }\end{array}$ & $\begin{array}{l}\text { Discrete return } \\
\text { airborne LiDAR } \\
\left(2 \text { points } / \mathrm{m}^{2}\right) \text { and } \\
\text { ATLAS image }\end{array}$ & $\begin{array}{l}\text { LiDAR CHM, } \\
\text { classified } \\
\text { imagery- } \\
\text { derived crown } \\
\text { form }\end{array}$ & $\begin{array}{l}\text { Individual tree } \\
\text { height }\end{array}$ & $\begin{array}{l}\text { Forest type } \\
\text { classification by } \\
\text { ATLAS, variable } \\
\text { window size filtering } \\
\text { for tree identification, } \\
\text { regression modelling }\end{array}$ & $\begin{array}{l}\text { Pine: height best LiDAR only } \\
R^{2}=0.96 \text {, combined sensor } \\
R^{2}=0.97 \\
\text { Deciduous: height best LiDAR } \\
\text { only } R^{2}=0.76 \text {, combined } \\
\text { sensor } R^{2}=0.79\end{array}$ & [79] \\
\hline $\begin{array}{l}\text { 15-year-old } \\
\text { loblolly pine } \\
\text { plantation }\end{array}$ & $\begin{array}{l}\text { Discrete return } \\
\text { airborne LiDAR } \\
\left(1-1.5 \text { points } / \mathrm{m}^{2}\right) \\
\text { and digital } \\
\text { imagery }(0.6 \mathrm{~m})\end{array}$ & $\begin{array}{l}\text { CHM and } \\
\text { intensity from } \\
\text { LiDAR; NIR } \\
\text { band from } \\
\text { digital } \\
\text { imagery }\end{array}$ & $\begin{array}{l}\text { Individual tree } \\
\text { identifica- } \\
\text { tion and } \\
\text { mean height }\end{array}$ & $\begin{array}{l}\text { Identify and count trees } \\
\text { with a focal window } \\
\text { passing over, derive } \\
\text { individual tree height } \\
\text { based on LiDAR }\end{array}$ & $\begin{array}{l}\text { Low density ( } 3 \text { m spacing): tree } \\
\text { identification accuracy image } \\
\text { only } R^{2} 0.924 \text {; LiDAR only, } \\
0.873 \text {; combined sensors, } \\
0.948 \text {. LiDAR } \\
\text { underestimated mean height } \\
\text { by } 0.38 \mathrm{~m} \text {, combined sensor } \\
\text { underestimated men height by } \\
0.50 \mathrm{~m} \\
\text { High density ( } 2.4 \mathrm{~m} \text { spacing): } \\
\text { tree identification accuracy } \\
\text { image only } R^{2} 0.786 \text {; LiDAR } \\
\text { only, } 0.647 \text {; combined } \\
\text { sensors, } 0.835 \text {. LiDAR } \\
\text { underestimated mean height } \\
\text { by } 0.15 \mathrm{~m} \text {, combined sensor } \\
\text { underestimated men height by } \\
0.42 \mathrm{~m}\end{array}$ & {$[77]$} \\
\hline
\end{tabular}

to explore the possibility of estimating forest volume and biomass in mixed-species forests. Popescu et al. [85] used spectral information and a LiDAR-derived CHM to delineate individual tree crowns and estimated tree height, basal area, volume and biomass at the plot level using linear regression models. Promising results were achieved for coniferous forests, with $R^{2}$ of 0.83 for volume and 0.82 for biomass. Though it was not quantified, the authors commented that an improvement in estimation accuracy was achieved with sensor fusion compared to LiDAR alone. Tonolli et al. [84] estimated tree stem volume at plot level with integration of low-density discrete return airborne LiDAR and multispectral IRS data. Height metrics and canopy variables extracted from LiDAR, together with spectral bands and band ratios extracted from IRS were correlated with the tree volume calculated from field inventory data. The combined sensor approach consistently produced higher $R^{2}$ and lower RMSE across all species compared to using either sensor alone. Wallerman and Holmgren
[86] predicted forest height, stem density and mean volume using a canonical correlation approach with inputs derived from both LiDAR and SPOT 5 HRG. Using the combined sensors achieved a more accurate mean stand volume estimation compared with using LiDAR only, resulting in a 2-4\% lower RMSE. Estornell et al. [87] used stepwise regression to find the best fit between LiDAR and spectral data from digital images against field measurements, they observed a significant improvement in modelling vegetation volume and biomass when both LiDAR and digital images were used, with $R^{2}$ increasing by $12 \%$ for volume and $29 \%$ for biomass compared to LiDAR-only models.

Most studies that we reviewed related to volume and/or biomass estimation using linear or multiple regression models to correlate LiDAR and optical sensor derived metrics with field measurements. However, OLS regression assumes that the explanatory variables are free of measurement errors, which is not realistic in remote sensing data inputs [88]. So, 
there has been increasing use of non-parametric modelling approaches to model forest volume with integrated LiDAR and spectral inputs. For example, Packalen and Maltamo [89] applied k most similar neighbour (k-MSN) imputation to predict species-specific volume at the stand level from airborne LiDAR-derived height metrics and aerial photographderived spectral and textural features. They found that the basal area and volume estimation using inputs from both sensors were accurate $(\mathrm{RMSE}=8.63$ and $10.36 \%$, respectively), although deciduous species showed higher errors than coniferous species (up to $34 \%$ higher RMSE). Cartus et al. [90] used a random forest $(\mathrm{RF})$ regression tree algorithm to predict stand-level canopy height and growing stock volume (GSV) over a large plantation area, using metrics derived from lowdensity discrete return LiDAR, RADAR sensor (ALOS PALS A) and Landsat ETM+. The fusion of RADAR and Landsat produced a minor improvement $(6 \%)$ in GSV estimation compared with using LiDAR. Although the study did not combine LiDAR with Landsat, it demonstrated a well-described methodology of using RF to model forests attributes with different sensor inputs.

Overall, optical sensors alone have not shown good performance in assessing forest volume and biomass; recent studies have demonstrated more significant improvement (up to $55 \%$ ) in modelling forest volume and biomass with the addition of LiDAR (Table 4). In terms of the measuring model performance, $R^{2}$ and RMSE are commonly used. Some studies also measure the bias of models [91]. A wide range of $R^{2}$ values was reported for data fusion approaches to estimating both biomass and volume. Biomass estimates ranged from $R^{2}=0.33$ to 0.82 , while volume estimates ranged from $R^{2}=$ 0.39 to 0.87 . In both cases, the lowest $R^{2}$ values were associated with estimates for deciduous forests. It appears that the biomass and volume for deciduous forests are more challenging to predict even with integration of LiDAR and optical sensors. This is an area where the development of speciesspecific techniques could significantly improve results. Furthermore, most studies reviewed in this section used lowto medium-density discrete return airborne LiDAR. Higherdensity LiDAR data or other forms of LiDAR acquisition, such as full waveform or terrestrial LiDAR, could potentially enhance the volume and biomass estimation particularly for deciduous forests due to analysis at a finer scale.

\section{Forest Age and Productivity}

Too few studies prevent firm conclusions from being drawn about the utility of sensor fusion for forest age and productivity estimation. Nevertheless, a summary of existing studies is presented. Forest age is highly correlated with growth and is a key attribute in forest information systems [92]. Stand age is an important variable but it may not always be available, such as for extensive national forest inventories [93] and uneven- aged natural forests [94]. Stand age data could be collected by field inventory and ring count analysis, but this is labourintensive and lacks consistency among different cruising crews $[95,96]$. Therefore, alternative approaches are desirable and remote-sensing techniques have been useful in estimating forest age. Research has shown that forest age is correlated with spectral reflectance of satellite imagery [97], especially the near infrared band and its derived vegetation indices [98]. Remote-sensing data is also capable of estimating age or age classes based on the differences in tree size, density, understory and canopy developments [99].

Because tree height is a strong predictor of forest age and active sensors directly measure height, studies have incorporated active sensors into forest age estimation to improve accuracy. Vega and St-Onge [100] developed a method of classifying unknown forest age based on existing age-height correlations and a time-series of CHMs derived from both aerial photography and LiDAR. CHMs were reconstructed for a period of 58 years based on historic AP-derived CHMs and a recent LiDAR-derived CHM. The RMSE of the estimated forest age was 7 years.

Forest site productivity refers to the potential tree height or aboveground wood volume for a particular forest site [101]. Understanding patterns in forest productivity is critical to forest resource management and influences tree species selection, design of optimal silvicultural regimes and forecasting timber yields [102]. Site productivity is often expressed as site index (SI), which is calculated as a function of the height of dominant or co-dominant trees at a reference age $[101,103]$. SI is a widely accepted quantification of productivity, as stand height or current height growth seems to correlate well with stand volume growth [101]. Also, compared to comprehensive assessments of forest site condition, SI is a simple variable that is relatively easy and inexpensive to measure and is generally not affected by management practices [104]. However, in order to estimate SI, stand age must be known.

The information on tree height at various ages used for building SI is normally derived from measurements of trees from sample plots [105]. However, field measurements sometimes cannot capture the spatial variation of forest productivity due to limited scale [100]. Improvements in availability of remotely sensed data such as LiDAR have yielded opportunities for estimating site productivity at increasingly finer scales. Studies have successfully utilised LiDAR to estimate dominant tree height and evaluate SI and site type for boreal forest in Finland [106], radiata pine in Australia [107] and eucalyptus plantations in Brazil [108] with given forest age. Alternatively, it is also possible to determine SI from singletree-based LiDAR to extract tree height at the individual tree level so that site index can be predicted at stand level. For example, Gatziolis [109] overlaid field-delineated individual tree crowns on a LiDAR point cloud to estimate dominant tree height; together with stand age information collected from the 


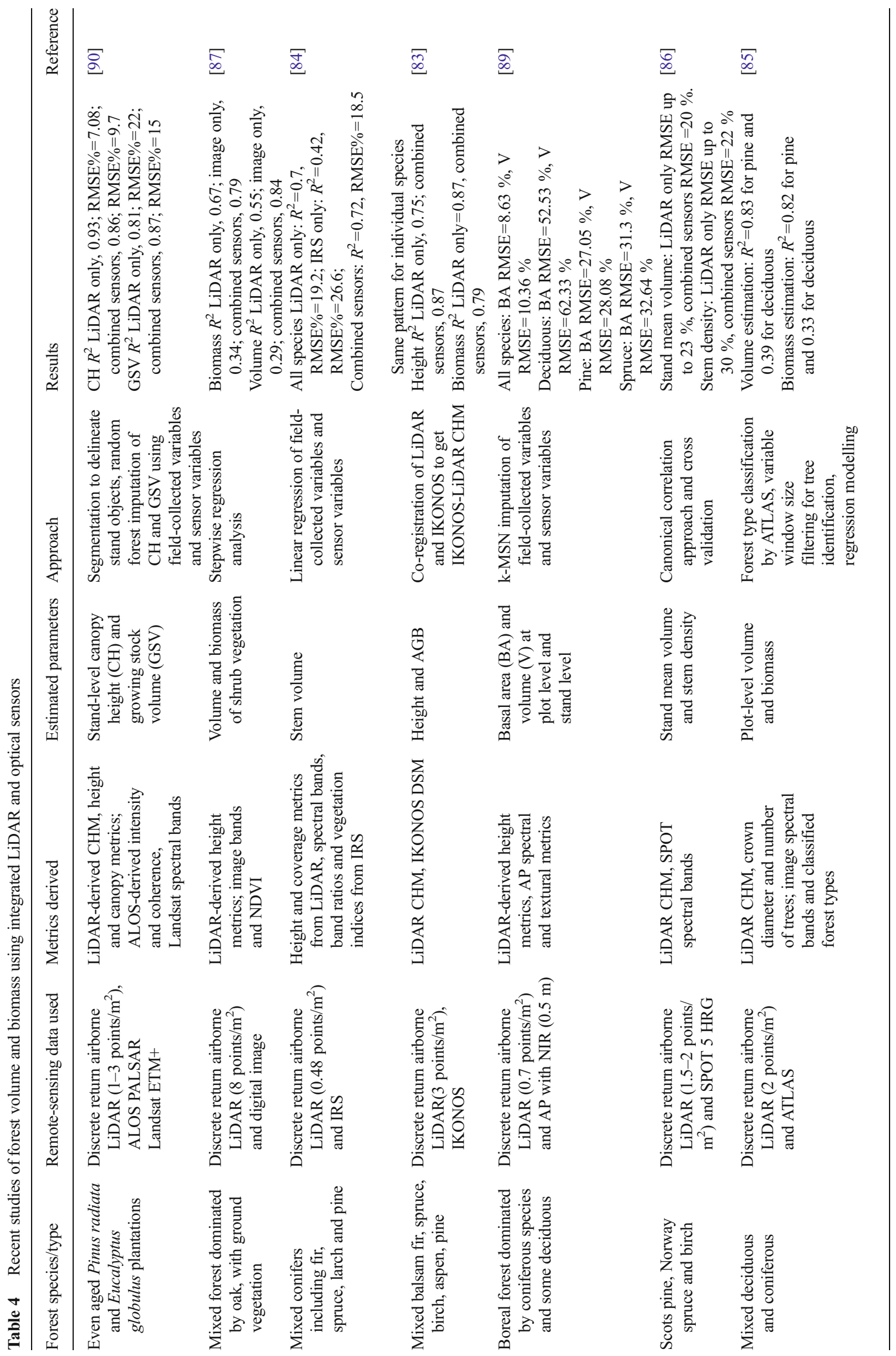


field, the SI at plot level was estimated. Chen and Zhu [104] used LiDAR-derived heights for individual trees in combination with stand age to predict stand level SI for radiata pine plantations in Australia.

Although LiDAR can accurately estimate tree heights and hence SI, the use of a LiDAR sensor alone to estimate productivity can be limiting, especially if forests lack stand age information. So far, very few studies have used integrated sensors to evaluate site productivity. Lefsky et al. [110] derived stand age by classifying a multi-temporal sequence of Landsat MSS and TM images and extracted stand height and aboveground net primary production of wood (NPP AW) from field measurements and LiDAR transects. In this study NPP AW, which is calculated as the average increment in biomass over a time period, was used as the indicator for forest productivity. A study mentioned earlier by Vega and St-Onge [100] used aerial photos obtained between 1945 and 2003 and recent LiDAR data to reconstruct CHMs over 58 years to estimate SI for jack pine over an extended region; stand SI was estimated with an average RMSE of $2.41 \mathrm{~m}$. The approach developed produced continuous SI and age maps in a spatially explicit way.

To date, too few integrated sensory studies have estimated forest age and/or productivity to prove or disprove the utility of the approach. Most age estimation research today is focussed on using a single sensor or using time-series analysis of remote sensing data $[94,97,98,110]$. Both productivity studies [100, 110] used optical sensors to gain stand age information in order to evaluate forest productivity, yet neither was considered a sensor fusion approach as the inputs from both LiDAR and optical sensors were not used simultaneously. As a consequence of the lack of previous studies, we are unable to draw conclusions of whether sensor fusion can improve forest age or productivity estimation, but promise has been shown.

\section{Conclusion}

The studies reviewed in this paper confirmed that fusion of primarily airborne LiDAR and optical sensors can improve many aspects of forest description. In particular, sensor fusion significantly improved delineation of forest areas (by up to $20 \%$ ), identification of species (by up to $21 \%$ ), and estimation of forest volume and biomass (by up to $55 \%$ ). As LiDAR alone has proven very effective in measuring canopy height, improvements in height estimation due to sensor fusion have been relatively small (between 1 and $7 \%$ ). The improvement of integrating LiDAR and optical sensors for forest age and productivity assessment cannot be fully evaluated due to the limited number of studies, yet they provide future research directions for sensor fusion application. Some studies also showed estimating forest height [79] and volume [89] of deciduous forests can be more challenging than coniferous forests possibly due to more complex forest structure and seasonal changes.
The approaches applied for classifying forest type and species, estimating forest structural variables with inputs from LiDAR and spectral data are relatively standardised. However, forest delineation appears to lack a common approach to evaluate performance. It was noted that some studies tend to compare the automated stand delineation results with manual interpretation $[58,59]$, yet in reality manual results are not always available. Mustonen et al. [53] assessed the variation in mean height, diameter and volume within delineated stands as a basis for evaluating results, which may be an appropriate approach for future studies. Moreover, modelling approaches for predicting forest height and volume commonly used linear or multiple regression analysis or non-parametric approaches such as kNN and random forest. None of these works for all situations; therefore, considerations should be given to selecting the most appropriate modelling approach. Brosofske et al. [91] provided a thorough review on modelling approaches for estimating forest variables, which serves as a reference for selecting regression models.

While fusion appears to be effective in a research environment, a challenge will be to operationalise the research such that forestry companies and governments can implement data fusion for improved forest management. Research on implementation will have to consider how to include data fusion into a standard forest mapping environment and also how to fully utilise the advantages of sensor fusion without incurring substantial extra costs. Additionally, the studies reviewed are primarily discrete return airborne LiDAR, which has been well developed and widely studied. Fusion of optical sensors with other forms of LiDAR such as fullwave form and terrestrial scanners is worth exploring in deriving an enhanced forest description.

\section{Compliance with Ethics Guidelines}

Conflict of Interest The authors of this paper declare that they have no conflicts of interest.

Human and Animal Rights and Informed Consent This article contains no studies with human or animal subjects performed by the author.

\section{References}

Papers of particular interest, published recently, have been highlighted as:

- Of importance

•- Of major importance

1. Food and Agriculture Organization. State of the world's forests 2014. Rome: FAO; 2014.

2. Boyd DS, Danson FM. Satellite remote sensing of forest resources: three decades of research development. Prog Phys Geogr. 2005;29(1):1-26. doi:10.1191/0309133305pp432ra. 
3. Roberts JW, Tesfamichael S, Gebreslasie M, van Aardt J, Ahmed FB. Forest structural assessment using remote sensing technologies: an overview of the current state of the art. South Hemisphere For J. 2007;69(3):183-203. doi:10.2989/shfj.2007.69.3.8.358.

4. Morgenroth J, Visser R. Uptake and barriers to the use of geospatial technologies in forest management. N Z J For Sci. 2013;43(1):16.

5. Wang Z, Boesch R. Color- and texture-based image segmentation for improved forest delineation. IEEE Trans Geosci Remote Sens. 2007;45(10):3055-62. doi:10.1109/TGRS.2007.896283.

6. Tuominen S, Pekkarinen A. Performance of different spectral and textural aerial photograph features in multi-source forest inventory. Remote Sens Environ. 2005;94(2):256-68. doi:10.1016/j.rse. 2004.10.001.

7. Haara A, Haarala M. Tree species classification using semiautomatic delineation of trees on aerial images. Scand J For Res. 2002;17(6):556-65. doi:10.1080/02827580260417215.

8. Kovats M. A large-scale aerial photographic technique for measuring tree heights on long-term forest installations. Photogramm Eng Remote Sens. 1997;63(6):741-7.

9. Dandois JP, Ellis EC. High spatial resolution three-dimensional mapping of vegetation spectral dynamics using computer vision. Remote Sens Environ. 2013;136:259-76. doi:10.1016/j.rse.2013. 04.005 .

10. Holmgren P, Thuresson T, Holm S. Estimating forest characteristics in scanned aerial photographs with respect to requirements for economic forest management planning. Scand J For Res. 1997;12(2):189-99. doi:10.1080/02827589709355400.

11. Campbell JB, Wynne RH. Introduction to remote sensing. New York: The Guilford Press; 2011.

12. Maselli F, Chirici G, Bottai L, Corona P, Marchetti M. Estimation of Mediterranean forest attributes by the application of kNN procedures to multitemporal Landsat ETM+ images. Int J Remote Sens. 2005;26(17):3781-96. doi:10.1080/01431160500166433.

13. Wolter PT, Townsend PA, Sturtevant BR. Estimation of forest structural parameters using 5 and 10 meter SPOT-5 satellite data. Remote Sens Environ. 2009;113(9):2019-36. doi:10.1016/j.rse. 2009.05.009.

14. Ingram JC, Dawson TP, Whittaker RJ. Mapping tropical forest structure in southeastern Madagascar using remote sensing and artificial neural networks. Remote Sens Environ. 2005;94(4): 491-507. doi:10.1016/j.rse.2004.12.001.

15. Cohen WB, Maiersperger TK, Gower ST, Turner DP. An improved strategy for regression of biophysical variables and Landsat ETM+ data. Remote Sens Environ. 2003;84(4):561-71. doi:10.1016/S0034-4257(02)00173-6.

16. Eklundh L, Harrie L, Kuusk A. Investigating relationships between Landsat ETM+ sensor data and leaf area index in a boreal conifer forest. Remote Sens Environ. 2001;78(3):239-51. doi:10. 1016/S0034-4257(01)00222-X.

17. Jensen RR, Binford MW. Measurement and comparison of leaf area index estimators derived from satellite remote-sensing techniques. Int J Remote Sens. 2004;25(20):4251-65. doi:10.1080/ 01431160410001680400.

18. Franco-Lopez H, Ek AR, Bauer ME. Estimation and mapping of forest stand density, volume, and cover type using the k-nearest neighbors method. Remote Sens Environ. 2001;77(3):251-74. doi:10.1016/s0034-4257(01)00209-7.

19. Hall RJ, Skakun RS, Arsenault EJ, Case BS. Modeling forest stand structure attributes using Landsat ETM+ data: application to mapping of aboveground biomass and stand volume. For Ecol Manag. 2006;225(1-3):378-90. doi:10.1016/j.foreco.2006.01. 014.

20. Zheng D, Rademacher J, Chen J, Crow T, Bresee M, le Moine J. Estimating aboveground biomass using Landsat 7 ETM+ data across a managed landscape in northern Wisconsin, USA.
Remote Sens Environ. 2004;93(3):402-11. doi:10.1016/j.rse. 2004.08.008

21. Kayitakire F, Hamel C, Defourny P. Retrieving forest structure variables based on image texture analysis and IKONOS-2 imagery. Remote Sens Environ. 2006;102(3-4):390-401. doi:10.1016/ j.rse.2006.02.022.

22. Immitzer M, Atzberger C, Koukal T. Tree species classification with random forest using very high spatial resolution 8-band Worldview-2 satellite data. Remote Sens. 2012;4(9):2661-93. doi:10.3390/rs4092661.

23. Shamsoddini A, Trinder JC, Turner R. Pine plantation structure mapping using WorldView-2 multispectral image. Int J Remote Sens. 2013;34(11):3986-4007. doi:10.1080/01431161.2013. 772308.

24.• Hudak AT, Lefsky MA, Cohen WB, Berterretche M. Integration of LiDAR and Landsat ETM plus data for estimating and mapping forest canopy height. Remote Sens Environ. 2002;82(2-3):397416. doi:10.1016/s0034-4257(02)00056-1. One of the first studies using fusion of LiDAR and optical sensor to estimate forest variable.

25. Wulder MA, Seemann D. Forest inventory height update through the integration of LiDAR data with segmented Landsat imagery. Can J Remote Sens. 2003;29(5):536-43.

26. Hyde P, Dubayah R, Walker W, Blair JB, Hofton M, Hunsaker C. Mapping forest structure for wildlife habitat analysis using multisensor (LiDAR, SAR/InSAR, ETM plus, QuickBird) synergy. Remote Sens Environ. 2006;102(1-2):63-73. doi:10.1016/j.rse. 2006.01.021.

27. Hudak AT, Evans JS, Smith AMS. LiDAR utility for natural resource managers. Remote Sens. 2009;1(4):934-51. doi:10.3390/ rs 1040934.

28. Peper PJ, McPherson EG, Mori SM. Equations for predicting diameter, height, crown width, and leaf area of San Joaquin valley street trees. J Arboric. 2001;27(6):306-17.

29. Gill SJ, Biging GS, Murphy EC. Modeling conifer tree crown radius and estimating canopy cover. For Ecol Manag. 2000;126(3):405-16. doi:10.1016/S0378-1127(99)00113-9.

30. Bi H, Fox JC, Li Y, Lei Y, Pang Y. Evaluation of nonlinear equations for predicting diameter from tree height. Can J For ResRevue Canadienne De Recherche Forestiere. 2012;42(4):789806. doi:10.1139/x2012-019.

31. Zianis D, Seura SM. Biomass and stem volume equations for tree species in Europe. Finnish Society of Forest Science, Finnish Forest Research Institute. 2005.

32. McIntosh ACS, Gray AN, Garman SL. Estimating canopy cover from standard forest inventory measurements in Western Oregon. For Sci. 2012;58(2):154-67. doi:10.5849/forsci.09-127.

33. Naesset E, Bjerknes K. Estimating tree heights and number of stems in young forest stands using airborne laser scanner data. Remote Sen Environ. 2001;78(3):328-40.

34. Packalen P, Maltamo M. Estimation of species-specific diameter distributions using airborne laser scanning and aerial photographs. Can J For Res-Revue Canadienne De Recherche Forestiere. 2008;38(7):1750-60. doi:10.1139/x08-037.

35. d'Oliveira MVN, Reutebuch SE, McGaughey RJ, Andersen HE. Estimating forest biomass and identifying low-intensity logging areas using airborne scanning LiDAR in Antimary State Forest, Acre State, Western Brazilian Amazon. Remote Sens Environ. 2012;124:479-91. doi:10.1016/j.rse.2012.05.014.

36. Naesset E. Airborne laser scanning as a method in operational forest inventory: status of accuracy assessments accomplished in Scandinavia. Scand J For Res. 2007;22(5):433-42. doi:10.1080/ 02827580701672147.

37. Hall SA, Burke IC, Box DO, Kaufmann MR, Stoker JM. Estimating stand structure using discrete-return LiDAR: an example from low density, fire prone ponderosa pine forests. For Ecol 
Manag. 2005;208(1-3):189-209. doi:10.1016/j.foreco.2004.12. 001.

38. Jensen JLR, Humes KS, Vierling LA, Hudak AT. Discrete return LiDAR-based prediction of leaf area index in two conifer forests. Remote Sens Environ. 2008;112(10):3947-57. doi:10.1016/j.rse. 2008.07.001.

39. Donoghue DNM, Watt PJ. Using LiDAR to compare forest height estimates from IKONOS and Landsat ETM+ data in Sitka spruce plantation forests. Int J Remote Sens. 2006;27(11):2161-75. doi: 10.1080/01431160500396493.

40. Eid T, Gobakken T, Naesset E. Comparing stand inventories for large areas based on photo-interpretation and laser scanning by means of cost-plus-loss analyses. Scand J For Res. 2004;19(6): 512-23. doi:10.1080/02827580410019463.

41. Naesset E, Gobakken T, Holmgren J, Hyyppa H, Hyyppa J, Maltamo M, et al. Laser scanning of forest resources: the Nordic experience. Scand J For Res. 2004;19(6):482-99. doi:10.1080/ 02827580410019553.

42. Lefsky MA, Cohen WB, Spies TA. An evaluation of alternate remote sensing products for forest inventory, monitoring, and mapping of Douglas-fir forests in western Oregon. Can J For Res-Revue Canadienne De Recherche Forestiere. 2001;31(1): 78-87. doi:10.1139/cjfr-31-1-78.

43. McInerney DO, Suarez-Minguez J, Valbuena R, Nieuwenhuis M. Forest canopy height retrieval using LiDAR data, mediumresolution satellite imagery and $\mathrm{kNN}$ estimation in Aberfoyle. Scot For. 2010;83(2):195-206. doi:10.1093/forestry/cpq001.

44. Pascual C, Garcia-Abril A, Cohen WB, Martin-Fernandez S. Relationship between LiDAR-derived forest canopy height and Landsat images. Int J Remote Sens. 2010;31(5):1261-80. doi: 10.1080/01431160903380656.

45. Ackermann F. Airborne laser scanning: present status and future expectations. ISPRS J Photogramm Remote Sens. 1999;54(2-3): 64-7. doi:10.1016/s0924-2716(99)00009-x.

46. Dubayah RO, Drake JB. Lidar remote sensing for forestry. J For. 2000;98(6):44-6.

47. Lim K, Treitz P, Wulder M, St-Onge B, Flood M. LiDAR remote sensing of forest structure. Prog Phys Geogr. 2003;27(1):88-106. doi:10.1191/0309133303pp360ra.

48. Wehr A, Lohr U. Airborne laser scanning - an introduction and overview. ISPRS J Photogramm Remote Sens. 1999;54(2-3):6882. doi:10.1016/s0924-2716(99)00011-8.

49.• Wulder MA, White JC, Nelson RF, Naesset E, Orka HO, Coops NC, et al. LiDAR sampling for large-area forest characterization: a review. Remote Sens Environ. 2012;121:196-209. doi:10.1016/j. rse.2012.02.001. This paper throughly reviews the LiDAR sampling studies and provide guidelines for characterising large-area forests.

50. Gleason CJ, Im J. A review of remote sensing of forest biomass and biofuel: options for small-area applications. Gisci Remote Sens. 2011;48(2):141-70. doi:10.2747/1548-1603.48.2.141.

51. Ustin SL, Gamon JA. Remote sensing of plant functional types. New Phytol. 2010;186(4):795-816. doi:10.1111/j.1469-8137. 2010.03284.x.

52. Eysn L, Hollaus M, Schadauer K, Pfeifer N. Forest delineation based on airborne LiDAR data. Remote Sens. 2012;4(3):762-83. doi:10.3390/rs4030762.

53. Mustonen J, Packalén P, Kangas A. Automatic segmentation of forest stands using a canopy height model and aerial photography. Scand J For Res. 2008;23(6):534-45. doi:10.1080/ 02827580802552446.

54. Nordkvist K, Granholm AH, Holmgren J, Olsson H, Nilsson M. Combining optical satellite data and airborne laser scanner data for vegetation classification. Remote Sens Lett. 2012;3(5):393-401. doi:10.1080/01431161.2011.606240.
55. Sasaki T, Imanishi J, Ioki K, Morimoto Y, Kitada K. Object-based classification of land cover and tree species by integrating airborne LiDAR and high spatial resolution imagery data. Landsc Ecol Eng. 2012;8(2):157-71. doi:10.1007/s11355-011-0158-z. A representative study of sensor fusion in enhancing land cover mapping and species classification.

56. Bork EW, Su JG. Integrating LiDAR data and multispectral imagery for enhanced classification of rangeland vegetation: a meta analysis. Remote Sens Environ. 2007;111(1):11-24. doi:10.1016/ j.rse.2007.03.011.

57. Dupuy S, Laine G, Tassin J, Sarrailh JM. Characterization of the horizontal structure of the tropical forest canopy using objectbased LiDAR and multispectral image analysis. Int J Appl Earth Obs Geoinf. 2013;25:76-86. doi:10.1016/j.jag.2013.04.001. This paper examined different segmentation parameters to optimise segmenttaion in the object-based classification process.

58. Wang Z, Boesch R, Ginzler C, editors. Integration of high resolution aerial images and airborne LiDAR data for forest delineation. The ISPRS XXXVII Congress. 2008; Beijing, China.

59. Haywood A, Stone C. Semi-automating the stand delineation process in mapping natural eucalpt forest. Aust For. 2009;74(1):1322. doi:10.1080/00049158.2011.10676341.

60. Machala M, Zejdova L. Forest mapping through object-based image analysis of multispectral and LiDAR aerial data. Eur J Remote Sens. 2014;47:117-31. doi:10.5721/EuJRS20144708.

61. Lu D, Weng Q. A survey of image classification methods and techniques for improving classification performance. Int $\mathrm{J}$ Remote Sens. 2007;28(5):823-70. doi:10.1080/ 01431160600746456.

62. Chubey MS, Franklin SE, Wulder MA. Object-based analysis of Ikonos-2 imagery for extraction of forest inventory parameters. Photogramm Eng Remote Sens. 2006;72(4):383-94.

63. Gao J. Classification accuracy assessment. Digital analysis of remotely sensed imagery. New York: McGraw Hill; 2009.

64. Foody GM. Status of land cover classification accuracy assessment. Remote Sens Environ. 2002;80(1):185-201. doi:10.1016/ S0034-4257(01)00295-4.

65. Orka HO, Dalponte M, Gobakken T, Naesset E, Ene LT. Characterizing forest species composition using multiple remote sensing data sources and inventory approaches. Scand J For Res. 2013;28(7):677-88. doi:10.1080/02827581.2013.793386.

66. Hirata Y, Furuya N, Suzuki M, Yamamoto H. Airborne laser scanning in forest management: individual tree identification and laser pulse penetration in a stand with different levels of thinning. For Ecol Manag. 2009;258(5):752-60. doi:10.1016/j.foreco.2009.05. 017.

67. Li W, Guo Q, Jakubowski MK, Kelly M. A new method for segmenting individual trees from the LiDAR point cloud. Photogramm Eng Remote Sens. 2012;78(1):75-84. doi:10. 14358/PERS.78.1.75

68. Yu XW, Hyyppa J, Vastaranta M, Holopainen M, Viitala R. Predicting individual tree attributes from airborne laser point clouds based on the random forests technique. ISPRS J Photogramm Remote Sens. 2011;66(1):28-37. doi:10.1016/j. isprsjprs.2010.08.003.

69. Holmgren J, Persson A, Soderman U. Species identification of individual trees by combining high resolution LiDAR data with multi-spectral images. Int J Remote Sens. 2008;29(5):1537-52. doi:10.1080/01431160701736471.

70. Ke YH, Quackenbush LJ, Im J. Synergistic use of QuickBird multispectral imagery and LiDAR data for object-based forest species classification. Remote Sens Environ. 2010;114(6):114154. doi:10.1016/j.rse.2010.01.002.

71. Zhang Z, Liu X. WorldView-2 satellite imagery and airborne LiDAR data for object-based forest species classification in a cool 
temperate rainforest environment. Developments in multidimensional spatial data models. Berlin: Springer Berlin Heidelberg; 2013. p. 103-22. A recent study utilising very high resolution imagery and LiDAR to classify forest species, the advantages of sensor fusion were well addressed.

72. Dalponte M, Bruzzone L, Gianelle D. Fusion of hyperspectral and LiDAR remote sensing data for classification of complex forest areas. IEEE Trans Geosci Remote Sens. 2008;46(5):1416-27. doi: 10.1109/TGRS.2008.916480.

73. Jones TG, Coops NC, Sharma T. Assessing the utility of airborne hyperspectral and LiDAR data for species distribution mapping in the coastal Pacific Northwest. Can Remote Sens Environ. 2010;114(12):2841-52. doi:10.1016/j.rse.2010.07.002.

74. Mountrakis G, Im J, Ogole C. Support vector machines in remote sensing: a review. ISPRS J Photogramm Remote Sens. 2011;66(3):247-59. doi:10.1016/j.isprsjprs.2010.11.001.

75. Lefsky M, Cohen W, Spies T. An evaluation of alternate remote sensing products for forest inventory, monitoring, and mapping of Douglas-fir forests in western Oregon. Can J For Res. 2001;31(1): 78-87.

76. Mora B, Wulder MA, White JC, Hobart G. Modeling stand height, volume, and biomass from very high spatial resolution satellite imagery and samples of airborne LiDAR. Remote Sens. 2013;5(5):2308-26. doi:10.3390/rs5052308. This applied study adopted the optimal modelling appraoch to model invididual forest structural atrributes.

77. McCombs JW, Roberts SD, Evans DL. Influence of fusing LiDAR and multispectral imagery on remotely sensed estimates of stand density and mean tree height in a managed loblolly pine plantation. For Sci. 2003;49(3):457-66.

78. Suárez JC, Ontiveros C, Smith S, Snape S. Use of airborne LiDAR and aerial photography in the estimation of individual tree heights in forestry. Comput Geosci. 2005;31(2):253-62. doi:10.1016/j. cageo.2004.09.015.

79. Popescu SC, Wynne RH. Seeing the trees in the forest: using LiDAR and multispectral data fusion with local filtering and variable window size for estimating tree height. Photogramm Eng Remote Sens. 2004;70(5):589-604. doi:10.14358/PERS.70.5. 589 .

80. Erdody TL, Moskal LM. Fusion of LiDAR and imagery for estimating forest canopy fuels. Remote Sens Environ. 2010;114(4): 725-37. doi:10.1016/j.rse.2009.11.002.

81. Rosenqvist A, Milne A, Lucas R, Imhoff M, Dobson C. A review of remote sensing technology in support of the Kyoto Protocol. Environ Sci Pol. 2003;6(5):441-55. doi:10.1016/s1462-9011(03) 00070-4.

82. Jochem A, Hollaus M, Rutzinger M, Höfle B. Estimation of aboveground biomass in alpine forests: a semi-empirical approach considering canopy transparency derived from airborne LiDAR data. Sensors. 2010;11(1):278-95.

83. St-Onge $\mathrm{B}, \mathrm{Hu} \mathrm{Y}$, Vega C. Mapping the height and above-ground biomass of a mixed forest using LiADR and stereo Ikonos images. Int J Remote Sens. 2008;29(5):1277-94. doi:10.1080/ 01431160701736505.

84. Tonolli S, Dalponte M, Neteler M, Rodeghiero M, Vescovo L, Gianelle D. Fusion of airborne LiDAR and satellite multispectral data for the estimation of timber volume in the Southern Alps. Remote Sens Environ. 2011;115(10):2486-98. doi:10.1016/j.rse. 2011.05.009.

85. Popescu SC, Wynne RH, Scrivani JA. Fusion of small-footprint LiDAR and multispectral data to estimate plot-level volume and biomass in deciduous and pine forests in Virginia. USA For Sci. 2004;50(4):551-65.

86. Wallerman J, Holmgren J. Estimating field-plot data of forest stands using airborne laser scanning and SPOT HRG data.
Remote Sens Environ. 2007;110(4):501-8. doi:10.1016/j.rse. 2007.02.028

87. Estornell J, Ruiz LA, Velazquez-Marti B, Hermosilla T. Estimation of biomass and volume of shrub vegetation using LiDAR and spectral data in a Mediterranean environment. Biomass Bioenergy. 2012;46:710-21. doi:10.1016/j.biombioe. 2012.06.023.

88. Berterretche M, Hudak AT, Cohen WB, Maiersperger TK, Gower ST, Dungan J. Comparison of regression and geostatistical methods for mapping leaf area index (LAI) with Landsat ETM+ data over a boreal forest. Remote Sens Environ. 2005;96(1):49 61. doi:10.1016/j.rse.2005.01.014.

89. Packalen P, Maltamo M. The k-MSN method for the prediction of species-specific stand attributes using airborne laser scanning and aerial photographs. Remote Sens Environ. 2007;109(3):328-41. doi:10.1016/j.rse.2007.01.005.

90. Cartus O, Kellndorfer J, Rombach M, Walker W. Mapping canopy height and growing stock volume using airborne LiDAR, ALOS PALSAR and Landsat ETM. Remote Sens. 2012;4(11):3320-45. doi:10.3390/rs4113320.

91. Brosofske KD, Froese RE, Falkowski MJ, Banskota A. A review of methods for mapping and prediction of inventory attributes for operational forest management. For Sci. 2014;60(4):733-56. doi: 10.5849/forsci.12-134.

92. Clark A, Daniels RF, Borders BE, editors. Effect of rotation age and physiographic region on weight per cubic foot of planted loblolly pine. Proceedings of the 13th Biennial Southern Silvicultural Research Conference. USDS, Forest Service, Southern Research Station, Asheville, NC. 2006.

93. Tomé J, Tomé M, Barreiro S, Paulo JA. Age-independent difference equations for modelling tree and stand growth. Can J For Res. 2006;36(7):1621-30.

94. Weber TC, Boss DE. Use of LiDAR and supplemental data to estimate forest maturity in Charles County, MD, USA. For Ecol Manag. 2009;258(9):2068-75. doi:10.1016/j.foreco.2009.08.001.

95. Avery TE, Berlin GL. Fundamentals of remote sensing and airphoto interpretation. 5th ed. Englewood Cliffs: Prentice Hall; 1992.

96. Avery TE, Burkhart HE. Forest measurements. vol Ed. 3. Dubuque: McGraw-Hill; 1983.

97. Cohen WB, Spies TA, Fiorella M. Estimating the age and structure of forests in a multi-ownership landscape of Western Oregon, USA. Int J Remote Sens. 1995;16(4):721-46.

98. Jensen JR, Qiu F, Ji MH. Predictive modelling of coniferous forest age using statistical and artificial neural network approaches applied to remote sensor data. Int J Remote Sens. 1999;20(14):280522.

99. Gemmell FM. Effects of forest cover, terrain, and scale on timber volume estimation with thematic mapper data in a rocky-mountain site. Remote Sens Environ. 1995;51(2):291-305. doi:10.1016/ 0034-4257(94)00056-s.

100. Vega C, St-Onge B. Mapping site index and age by linking a time series of canopy height models with growth curves. For Ecol Manag. 2009;257(3):951-9. doi:10.1016/j.foreco.2008.10.029.

101. Skovsgaard JP, Vanclay JK. Forest site productivity: a review of the evolution of dendrometric concepts for even-aged stands. Forestry. 2008;81(1):13-31. doi:10.1093/forestry/cpm041.

102. Bontemps J-D, Bouriaud O. Predictive approaches to forest site productivity: recent trends, challenges and future perspectives. Forestry. 2014;87(1):109-28. doi:10.1093/forestry/cpt034.

103. Sharma RP, Brunner A, Eid T. Site index prediction from site and climate variables for Norway spruce and Scots pine in Norway. Scand J For Res. 2012;27(7):619-36. doi:10.1080/02827581. 2012.685749.

104. Chen Y, Zhu X. Site quality assessment of a Pinus radiata plantation in Victoria, Australia, using LiDAR technology. Southern 
For: J For Sci. 2012;74(4):217-27. doi:10.2989/20702620.2012. 741767.

105. Raulier F, Lambert M-C, Pothier D, Ung C-H. Impact of dominant tree dynamics on site index curves. For Ecol Manag. 2003; 184(13):65-78. doi:10.1016/S0378-1127(03)00149-X.

106. Holopainen M, Vastaranta M, Haapanen R, Yu X, Hyyppä J, Kaartinen $\mathrm{H}$, et al. Site-type estimation using airborne laser scanning and stand register data. Photogramm J Fin. 2010;22:16-32.

107. Rombouts J, Ferguson IS, Leech JW. Campaign and site effects in LiDAR prediction models for site-quality assessment of radiata pine plantations in South Australia. Int J Remote Sens. 2010;31(5):1155-73. doi:10.1080/01431160903380573.
108. Packalén P, Mehtätalo L, Maltamo M. ALS-based estimation of plot volume and site index in a eucalyptus plantation with a nonlinear mixed-effect model that accounts for the clone effect. Ann For Sci. 2011;68(6):1085-92. doi:10.1007/s13595-011-0124-9.

109. Gatziolis D. LIDAR-derived site index in the US pacific northwest - challenges and opportunities. The International Archives of the Photogrammetry, Remote Sensing and Spatial Information Sciences, Espoo, Finland. 2007. 36(Part 3/W52):pp. 136-43.

110. Lefsky MA, Turner DP, Guzy M, Cohen WB. Combining LiDAR estimates of aboveground biomass and Landsat estimates of stand age for spatially extensive validation of modeled forest productivity. Remote Sens Environ. 2005;95(4):549-58. doi:10.1016/j.rse. 2004.12.022. 